DOI 10.4467/25439561KSR.18.008.9366

\author{
ANNA RAŹNY (D) https://orcid.org/0000-0003-0752-9647 \\ em. prof. Uniwersytetu Jagiellońskiego \\ Kraków
}

\title{
HEROIZM W GUŁAGU
}

\section{HEROISM IN THE GULAG}

\section{Streszczenie}

Dla podjętego tematu istotne jest znaczenie występujących w tytule pojęć. Heroizm wyraża aksjologiczny i metafizyczny wymiar poświęcenia człowieka w imię wartości fundamentalnych dla sensu i celu jego istnienia. To właśnie pojęcie podpowiada antropologiczno-filozoficzne kryteria interpretacji literatury stanowiącej świadectwo życia w łagrze. Gułag wnosi natomiast do tak określonej interpretacji perspektywę historyczno-ideologiczną. Prezentując postawy heroiczne w Gułagu, literatura łagrowa potwierdza określone przez Maxa Schelera znaczenie heroizmu jako postawy moralnej i zarazem egzystencjalnej. Wyrasta ona z pozycji przekraczania własnego ja w ofiarnym akcie poświęcenia w imię wybranych wysokich wartości duchowych, moralnych, kulturowych. W ofiarnym akcie ja ludzkiego (aż do ofiary własnego życia) ujawnia się metafizyczna istota wartości, dla której jest on dokonywany. Ujawnia się także perspektywa metafizycznej nadziei na inne - prawdziwe życie, nade wszystko po śmierci. Heroizm w Gułagu stanowił nie tylko zaprzeczenie rozpaczy i nicości, ale również świadectwo poświęcenia dla wartości przewyższającej system obozowy i ideologię komunizmu. Poświęcenie to oznaczało zgodę na cierpienie i śmierć w imię wybranej wartości. Literatura łagrowa podaje przykłady heroicznych postaw zajmowanych w imię religii, drugiego człowieka, wolności, rodziny, sztuki. Najbardziej reprezentatywne pod tym względem są utwory A. Sołżenicyna, W. Szałamowa, E. Giznburg, W. Bukowskiego. One też są przywoływane w niniejszej pracy.

\section{Abstract}

The meaning of the concepts appearing in the title is of significance for the topic undertaken here. Heroism expresses the axiological and metaphysical dimension of human sacri-

\section{cc) $(9)$}


fice in the name of values fundamental to the sense and purpose of human existence. This very concept suggests anthropological-philosophical criteria of interpreting literature constituting a testimony to life in a prison camp. The Gulag, however, adds a historical-ideological perspective to such an interpretation. In presenting heroic attitudes in the Gulag, prison camp literature confirms the meaning of heroism as a moral and simultaneously existential stance, as described by Max Scheler. It originates from the position of transgressing one's own $I$ in the sacrificial act of self-sacrifice in the name of selected higher spiritual, moral and cultural values. In the sacrificial act of the human $I$ (even up to the act of sacrificing one's own life), the metaphysical essence of the values for which the act is being carried out is disclosed. The metaphysical perspective of hope for a different - authentic - life, in particular after death, is also discused. Heroism in the Gulag was not only the negation of despair and nothingness, but also a testimony of sacrifice for the value surpassing the camp system and the communist ideology. This sacrifice signified a reconciliation with suffering and death in the name of the selected value. Camp literature presents examples of heroic attitudes taken on in the name of religious values, a fellow human being, freedom, family or art. The most representative in this aspect are the works of: A. Solzhenitsyn, W. Shalamov, E. Ginzburg, W. Bukovsky. They are also cited in this work.

Słowa kluczowe: heroizm, cierpienie, śmierć, wartości, Gułag

Keyw ords: heroism, suffering, death, values, Gulag

Występujące w tytule słowa-klucze łączą dwie perspektywy ludzkiej egzystencji. Heroizm wskazuje na aksjologiczno-metafizyczną, Gułag - na historyczno-ideologiczną.

Mówiąc o heroizmie, pamiętać musimy, iż nie ma on jasno określonego znaczenia. Jest postawą moralną wyrastającą z pozycji przekraczania własnego ja w ofiarnym akcie poświęcenia w imię wybranych wysokich wartości duchowych, moralnych, kulturowych. W ofiarnym akcie ja ludzkiego (aż do ofiary własnego życia) ujawnia się metafizyczna istota wartości, dla której jest on dokonywany i perspektywa metafizycznej nadziei na inne - prawdziwe - życie po śmierci. Na gruncie antropologii personalistycznej (Gabriel Marcel), ale także filozofii dialogu (Józef Tischner), filozofii wartości (Max Scheler) czy też psychologii i psychiatrii (Viktor Frankl) jako stała dana heroizmu eksponowana jest odwaga. Wyraża ona bowiem nie tylko gotowość do ofiarnego aktu, ale również wolność od dyktatury ciała, emocji czy presji otoczenia, które hamuja ja, powstrzymując je przed ofiarnym czynem. Antropologia personalistyczna eksponuje jednocześnie drugą stałą daną heroizmu - nadzieję. W nadziei widoczne jest nade wszystko ukierunkowanie osoby na owo prawdziwe życie, które jest gdzie indziej - na wartość, która przewyższa heroiczną osobę i jest przepustką do tego życia. Postawę poświęcenia w perspektywie nadziei trafnie ujął Marcel, pisząc: 
„Nadzieja z istoty swej jest jak gdyby gotowością duszy zaangażowanej dostatecznie głęboko w doświadczenie komunii, by mogła dokonać aktu transcendentnego, odmiennego od aktu woli i poznania, którym to aktem stwierdza ona żywą wieczność; przy tym doświadczenie to stanowi jednocześnie rękojmię i przesłanki owej wieczności"1.

W perspektywie nadziei heroizm nabiera jej mocy, przejawiającej się w potwierdzaniu sensu i celu życia ludzkiego. Wyprowadza heroiczną osobę z mroku cierpienia i śmierci. Chroni ją - jak podkreśla Marcel - przed pokusą rozpaczy. Ta bowiem jest dla człowieka więzieniem, które zamyka go w czasie wykluczającym jakiekolwiek zmiany - nastawionym na powtarzalność. Dla więźnia Gułagu - zeka pokonanie rozpaczy, jak pokazuje literatura łagrowa, i wejście w horyzont nadziei było najważniejszym impulsem do wybrania heroicznej postawy wobec unicestwiającego systemu. Heroizm więźnia czerpie z nadziei nastawienie na zmianę, na odwrócenie sytuacji, w której cierpienie i zagrożenie śmierciąjest trwałym elementem łagrowego życia. Aleksander Sołżenicyn do heroicznych więźniów zalicza nade wszystko ludzi wierzących. W Archipelagu GUŁag (Архипелаг ГУЛаг) ich gotowość poświęcenia własnego życia dla kryjących jego sens wartości duchowych nazywa determinacją.

„A jak bytują w obozie (już nieraz wspominaliśmy o nich) ludzie naprawdę religijni? Obok postaci w tej książce opisanych, kroczą oni bez trwogi i wahań, przeciagając przez cały Archipelag jak procesja z niewidzialnymi gromnicami. Padają szeregiem, jak od serii cekaemu, nowy szereg wyrasta na tym miejscu i wciąż dalej kroczy. Determinacja, jakiej nie znał dotąd wiek XX!"’2.

W wymiarze moralnym była to determinacja na rzecz dobra, którego zapowiedzią było powstrzymywanie się od zła. W tym wymiarze determinacja jako stała dana heroicznej postawy przejawiała się w stosunku do drugiego więźnia. Samo cierpliwe znoszenie przymusowej obecności współwięźnia całą dobę było już znakiem powstrzymywania się od zła i otwarcia na dobro wymagające heroicznego poświęcenia. W świecie łagrów zło moralne stało się chlebem powszednim zeka, jego szansą na przeżycie. Gułag nie był bowiem odejściem od systemu komunistycznego ani też jego wypaczeniem. Był istotą systemu. W radykalny i przyspieszony sposób realizował podstawowe cele ideologii komunistycznej i państwa totalitarnego,

${ }^{1}$ G. Marcel, Zarys fenomenologii i metafizyki nadziei, [w:] G. Marcel, Homo viator. Wstęp do metafizyki nadziei, tłum. P. Lubicz, Warszawa, PAX, 1984, s. 70.

${ }^{2}$ A. Sołżenicyn, Archipelag GUŁag. 1918-1956, tłum. J. Pomianowski, t. II, cz. III-IV, Warszawa, Nowe Wydawnictwo Polskie, 1991, s. 540. Kolejne cytaty z Archipelagu GUŁag pochodzą z tego wydania - tom i strona zaznaczone zostały w nawiasach. 
stanowiącego jej instrument. W sferze społecznej celem tym było stworzenie komunistycznego społeczeństwa. W sferze antropologicznej - ukształtowanie nowego człowieka typu homo sovieticus ${ }^{3}$. Dlatego też komunizm miał charakter nie tylko ideowo-polityczny i społeczny, ale również cywilizacyjny i kulturowy. Walka o nowego człowieka toczyła się bowiem przede wszystkim na polu cywilizacji i kultury. Antropologia komunistyczna miała wybitnie negatywny charakter - wysunęła koncepcję człowieka odciętego od Transcendencji, jednowymiarowego, słabego, niezdolnego do przekraczania swych ograniczeń, niezdolnego do takiej wolności, której nieodłącznym atrybutem jest odpowiedzialność. Na jej gruncie ujawniła się negatywna aksjologia służąca kształtowaniu homo sovieticus - człowieka, pozbawionego świadomości religijnej, kulturowej, narodowej; podporządkowanego całkowicie komunistycznej ideologii. Człowieka pozbawionego świadomości aksjologicznej niezdolnego do rozróżniania dobra i zła, prawdy i fałszu.

Fundamentalną rolę w koncepcji nowego człowieka odegrała marksistowska idea wolności, zdeterminowana ideą komunistycznego społeczeństwa. Marks zaprzeczał w niej wolności liberalnej, co akcentują m.in. A. Walicki, Isaiah Berlin, Leszek Kołakowski, czy Friedrich Hayek ${ }^{4}$. Nade wszystko jednak, czego wymienieni badacze nie podkreślają, negował ideę wolności zrodzoną na gruncie chrześcijaństwa, w szczególności jej personalistyczną koncepcję. Dla marksistowskiego ujęcia wolności koncepcja chrześcijańska rysowała się jako największe zagrożenie. Wyróżniona przez św. Tomasza wolność ontologiczna oraz wolność moralna przeczyły marksistowskiej idei konieczności. Wolność ontologiczna gwarantuje bowiem sam akt wyboru i zdolność dokonywania wyboru niezależnie od procesów dziejowych. Wolność moralna jest natomiast przejawem świadomości aksjologicznej, stanowiącej właściwą człowiekowi próbę samookreślenia siebie poprzez zdolność wyboru wartości. To generalnie podważało nie tylko ideę konieczności komunizmu, ale również społeczny i historiozoficzny atrybut wolności jako nadrzędny. Najsilniej opozycyjność chrześcijańskiej koncepcji wolności wobec marksistowskiej ujawnia się w wolności moralnej. Ta ostatnia oznacza bowiem autonomię człowieka w wymiarze duchowym, podmiotowość osoby odrzucającą podporządkowanie jakiejkolwiek ideologii.

Z punktu widzenia zarówno wolności ontologicznej, jak i wolności wewnętrznej - moralnej - ideał komunizmu i materialistyczna wizja postępu ludzkości stanowią nie tylko iluzję, ale również szczególną formę uzurpacji metafizycznej. Łudzą

${ }^{3}$ Por. m.in. A. Raźny, Literatura wobec zniewolenia totalitarnego. Warłama Szałamowa świadectwo prawdy, Kraków, Wydawnictwo Uniwersytetu Jagiellońskiego, 1999.

${ }^{4}$ Takie ujęcie marksistowskiej koncepcji wolności przedstawia szczegółowo m.in. A. Walicki w książce Marksizm i skok do królestwa wolności. Dzieje komunistycznej utopii, Warszawa, PWN, 1996. 
obietnicą tego, co niemożliwe w materialistycznej filozofii człowieka i materialistycznej koncepcji dziejów - osiągnięciem Absolutu. Jednocześnie zaś usuwają z nowej antropologii pojęcie personalnej odpowiedzialności moralnej i zasady jej ponoszenia jako nieusuwalnego członu wolności, rozumianego najczęściej jako jej konsekwencja. Wysuwany w ramach tej antropologii ideał nowego człowieka jest wyzwolony z odpowiedzialności nade wszystko w sferze zła moralnego. Nie zna pojęcia odpowiedzialności moralnej i zasad jej ponoszenia. Tymczasem odpowiedzialność właśnie sprawia, że człowiek osiąga pełnię swojego ja, staje się - bardziej sobą - i umacnia fundamenty swojej godności. Poprzez kategorię odpowiedzialności weryfikuje nie tylko granice swojej wolności, ale również tożsamość osobową jako bycie sobq wobec wartości moralnych. Te powiązania sfery ontologii i moralności w odniesieniu do człowieka jako „działającego podmiotu” trafnie ujmuje T. Ślipko:

„Odpowiedzialność oznacza znowu taką wlaściwość tegoż podmiotu, mocą której dobro lub zło moralne zawarte $w$ treści spełnionego przezeń czynu wyciska swe znamię na moralnej treści jego osobowości, wskutek czego ponosi on związane z czynem konsekwencje (pogrubienie T.Ś.).

Właśnie na podstawie odpowiedzialności człowiek w ostatecznym rozrachunku staję się moralnie ukształtowanym podmiotem, a zarazem uczestnikiem uzależnionej od moralnego postępowania nagrody lub kary, szczęścia lub cierpienia"5.

Heroizm w Gułagu łączył wszystkie aspekty wolności w ujęciu personalistycznym - wolność ontologiczną, wolność wewnętrzną w jej wymiarze moralnym i odpowiedzialność. Wszystkie też ujawniały się w relacji więźnia z drugim człowiekiem. W relacjach tych heroiczny więzień był wolny. Ten natomiast, który uzależniał je od czynników zewnętrznych - warunków życia, katorżniczej pracy, komunistycznej ideologii - potwierdzał swoją niezdolność do wolnego wyboru - głównie wartości moralnych - i do odpowiedzialności za ten wybór. Dlatego wrogiem heroicznego więźnia stawał się nie tylko przedstawiciel obozowej władzy, ale nade wszystko zniewolony wewnętrznie drugi więzień.

Andrzej Morka, pisząc o doświadczeniu Boga w Gułagu, podkreśla moralny i duchowy wymiar relacji międzyosobowych w przestrzeni łagrowej:

„Drugi człowiek jawił się tedy jako wróg i nieprzyjaciel. W miejscu wezwania do komunii osób pojawiło się wezwanie do nienawiści i obojętności. Ludzkie ciało pod wpływem ogromnego zagęszczenia obcych ciał zmieniało funkcję znaku. Stawało się

${ }^{5}$ T. Ślipko, Zarys etyki ogólnej, Kraków, WAM, 2004, s. 419-420. 
znakiem anty-komunii i anty-dialogu. Zaistniałe warunki nie sprzyjały zdolności przekraczania siebie, wychodzeniu z siebie ku drugim, nawiązywania bezpośredniej relacji osobowej, ale pchały osobę ku konieczności zamknięcia się w sobie, w przestrzeń odosobnienia i separacji. Następowało jakby cofnięcie się na płaszczyźnie bytowej. Osoba jest bowiem tylko w takiej mierze, w jakiej istnieje dla kogoś innego, dla innej osoby"6.

Obojętność na los współwięźnia nie tylko wykluczała heroizm i sprzyjała złu, ale również stawała się źródłem autodestrukcji zeka. Prowadziła do jego degradacji moralnej i umacniała te wymiary łagrowej egzystencji, które sprawiały, że pragnienie prawdziwego życia, na które wskazuje nadzieja metafizyczna, nie mogło zaistnieć. Konkluzja Morki o anty-komunii i anty-dialogu jako wstępnym etapie degradacji moralnej jest niemal identyczna z refleksją Warłama Szałamowa, który ponad 20 lat spędził w obozach kołymskich i w swych opowiadaniach daje potwierdzone osobistym doświadczeniem świadectwo prawdy o degradacji moralnej więźnia. Podkreśla przy tym, że była to przemiana tożsamości osobowej, dokonująca się za jego przyzwoleniem. Antropologia komunistyczna - negatywna w każdym aspekcie - była bowiem obliczona na akceptację przez samego deformowanego w jej ramach człowieka. W opowiadaniu Inżynier Kisielow (Инженер Киселев) Szałamow pisze, że 99 procent więźniów ulegało degradacji moralnej . Jest w tej ocenie o wiele bardziej surowy niż Sołżenicyn.

„To straszne - podkreśla - zobaczyć łagier. Żaden człowiek na świecie nie powinien znać łagrów. W łagrowym doświadczeniu wszystko jest negatywne - co do jednej minuty. Człowiek staje się jedynie gorszy. I nie może być inaczej” (t. II, s. 73).

Nieco dalej kontynuuje tę konstatację, zwracając uwagę na moralny wymiar doświadczenia łagrowego - zdecydowanie negatywny:

„Łagier był dla człowieka wielką próbą sił charakteru, zwykłej ludzkiej moralności i dziewięćdziesiąt dziewięć procent ludzi nie wytrzymało tej próby. Wraz z tymi, co nie wytrzymali, umierali ci, co zdołali wytrzymać, starając się być lepszymi niż wszyscy, twardszymi dla samych siebie" (t. II, s. 74).

Jak to pokazuje w swoich opowiadaniach, człowiek w świecie łagrów staje się gorszy z własnej woli - zamyka się na prawdę o sensie i celu własnego istnienia, a zarazem na nadzieję.

${ }^{6}$ A. Morka, Doświadczenie Boga w GUŁ-agu, Sandomierz, Wydawnictwo Diecezji Sandomierskiej, 2007, s. 33-34.

${ }^{7}$ W. Szałamow, Inżynier Kisielow, [w:] Opowiadania kołymskie, tłum. J. Baczyński, t. I-III, Gdańsk, ATEXT, 1991, s. 262. Kolejne cytaty ze zbioru Opowiadań kołymskich pochodzą z tego wydania; tom i strona cytowanego utworu zostały podane w nawiasach. 
Sołżenicyn potwierdza w Archipelagu GUŁag demoralizujący wpływ łagru na więźnia, choć nie uważa, iż ogromna większość - owe 99 procent w skali Szałamowa - temu wpływowi ulegała. W części IV drugiego tomu, pisząc o duszy i drucie kolczastym, notuje:

„7) ROZKŁAD MORALNY. W utrzymującej się przez dziesięciolecia atmosferze strachu i wiarołomstwa ci, którym udało się uniknąć zguby uratowali tylko swoją powłokę cielesna, ocaleli tylko zewnętrznie. Wewnątrz jest próchno" (t. II, s. 557).

Autor Opowiadań kotymskich (Кольмские рассказы) w swych literackich ujęciach zdemoralizowanego więźnia wielokrotnie podkreśla, że jego świadomość została poddana rozpaczy budującej fatalistyczny obraz świata. Taka właśnie świadomość sprawiała, że obóz robił wrażenie zbiorowiska niemych, nierozumiejących go istot, na co zwraca uwagę Morka. Obojętność, która jej towarzyszyła, stawała się normą życia i normą moralną. Jak pisze Szałamow w opowiadaniu Na suchej racji (Сухим пайком):

„Każda ingerencja w to, co niesie los, w wolę bogów, była czymś, co nie przystoi i sprzeczne jest z kodeksem postępowania w łagrze" (t. III, s. 262).

Obojętność nie mogła być heroiczna, choć była łudząco podobna do cierpliwości wobec innego ja, o której mówi Marcel. Obojętność była świadectwem anihilacji samoświadomości i wolności moralnej, które mogłyby pobudzić w więźniu ideę ofiary w imię wartości o wyższej randze aksjologicznej i nadzieję na inne życie gdzie indziej. Nie dawała szans na towarzyszące heroizmowi doskonalenie wewnętrzne. Mogła - co najwyżej - inspirować stoicką rezygnację.

W obojętności na los własny i współtowarzyszy przejawiała się nowa świadomość zbędności nie tylko w świecie totalitarnym, ale również w skali całego istnienia. Obojętność usuwała w cień wszystkie te wartości, na których mogłaby zaistnieć nadzieja na uchwycenie duchowego sensu życia: poznawcze (prawda), moralne (dobro), estetyczne (piękno). Obojętny więzień nie utożsamiał się z nimi, stawał się bowiem kimś nowym. Nie był to jednak oczekiwany przez ideologów komunistycznych nowy człowiek. To był człowiek zrozpaczony. Gabriel Marcel określa bliżej takie stany duchowe i psychiczne:

„Człowiek bezczynny czy zrozpaczony, o którym mówiłem, nie tylko jest istotą, która już nic nie daje, ale która utraciła możność ożywienia świata i której wydaje się, że została w ten świat jak gdyby rzucona i że jednocześnie jest w nim zbyteczna”».

${ }^{8}$ G. Marcel, Wartość i nieśmiertelność, [w:] idem, Homo viator..., op.cit., s. 150. 
Obojętność więźnia w istnieniu i na istnienie powodowała, że on sam traktował swe życie jako nieautentyczne, życie „w nawiasie”, zawieszone w próżni. Jego bezczynność miała charakter duchowy. Więzień nie podejmował żadnego wysiłku, aby odszukać utracony sens życia. Filozofia personalizmu bezczynność taką wiąże bezpośrednio z rozpaczą.

„Bezczynność - pisze Marcel - graniczy tu z rozpaczą, rozpacz bowiem nie jest niczym innym jak bezczynnością, która osiagnęła najbardziej wyostrzoną świadomość samej siebie, jest - by użyć tu nieco barbarzyńskiego słowa - brakiem zaangażowania (désengagement), dezercją świadomości, która utraciła już łączność z rzeczywistością"’.

Rozpacz była jeszcze głębszym upadkiem ducha niż fatalizm. Dlatego nie tylko uniemożliwiała osiaganie doskonałości moralnej, która rodziła heroizm, ale wręcz popychała więźnia do zła. Zrozpaczony człowiek w obozie otwierał się na zło w zastraszająco szybkim tempie. Jego tożsamość stawała się tożsamością złego moralnie człowieka. Pisze o tym lakonicznie Szałamow w Sentencji (Сентениия):

„Było mi obojętne - mówi narrator - czy będą mi kłamać, czy nie, istniałem poza prawda, poza kłamstwem" (t. III, s. 262).

Obojętność na prawdę i kłamstwo była jednocześnie obojętnością na dobro i zło. W większości literackich świadectw obozowych została ona sprowadzona do relacji: więzień i jego strażnik, ofiara i kat - i przeważnie przypisywana jest właśnie strażnikowi, katowi, przedstawicielom systemu obozowego. Szałamow zauważa, że obojętność moralna obejmuje w szybkim tempie przede wszystkim więźniów, bowiem ich strażnicy i oprawcy wcześniej ulegli deprawacji. Gułag generujący - według określenia Morki - anty-komunię i anty-dialog - czynił nieludzkimi wszelkie relacje międzyosobowe, również, czy wręcz nade wszystko, między więźniami. W takim świecie idea poświęcenia i perspektywa nadziei wymagały ogromnego wysiłku duchowego. Czynniki zewnętrzne wysiłek ten jedynie potęgowały. Jacek Salij we wstępie do pracy Morki podkreśla, że te właśnie czynniki odgrywały rolę decydującą w szybkiej degradacji moralnej więźnia:

„Anty-przestrzeń tworzył zarówno bezkres syberyjskich bezdroży, jak ciagłe, przymusowe i kompletnie arbitralne przenoszenie z miejsca na miejsce, zarówno zostawianie ludzi bez obrony na pastwę potężnych żywiołów, jak niewiarygodnie prymitywne warunki życia (brak odpowiedniej odzieży mimo bardzo surowego klimatu, autentyczny głód i brud, brak elementarnej intymności w miejscach stanowiących parodię ludzkiego domu itp.). Wpędzenie w anty-czas polegało na tym, że zesłańców i łagierników

${ }^{9}$ Ibidem, s. 150. 
chciano pozbawić wszelkiej nadziei. Każdy kolejny dzień miał potwierdzać poczucie, że ich życie nie ma sensu i prowadzi do marnego końca. Urządzono im życie bez możliwości planowania własnej przyszłości i decydowania o sobie, bez możliwości rozwijania się i dokonywania wyborów. Anty-dialog i anty-komunia były niejako konieczną konsekwencją sytuacji, kiedy powszechny głód i nędza rodziły plagę kradzieży, podejrzliwości a nawet rozbojów. Wzajemne zaufanie niszczyło organizowane przez prześladowców donosicielstwo" $"$.

$\mathrm{Z}$ trudem rodząca się w takich warunkach nadzieja jako fundament heroizmu często traciła swój metafizyczny charakter i przekształcała się w zwykły optymizm, który nie kształtował jednak postawy heroicznej. Był bowiem jedynie kalkulacją aksjologiczną obliczoną nie na prawdziwe życie, które jest gdzie indziej, lecz na dalsze trwanie w anty-przestrzeni i anty-czasie. Pisze o tym Eugenia Ginzburg w Stromej ścianie (Kрутой марируm):

„Dar wdzięczności - to rzadki dar. I nie jestem tutaj wyjątkiem. Wszyscy wzywamy z rozpaczą: „Dopomóż!”, kiedy giniemy, ale gdy tylko zagrożenie mija, zapominamy, kto nas przed nim obronił. Spotkałam na mojej drodze krzyżowej dziesiątki, a nawet setki jak najbardziej ortodoksyjnych marksistów, którzy w chwilach grozy zwracali pełne udręki oczy ku Temu, którego istnieniu tak autorytatywnie przeczyli w swojej wieloletniej praktyce oświatowej. Ci jednak, którzy ocaleli, nie Bogu składali podziękę, lecz w najlepszym razie Nikicie Chruszczowowi. Albo w ogóle jej nie składali. Taką już mamy naturę""

Na gruncie etyki takie zachowanie może być określone jako radykalny pragmatyzm bądź zwykła kalkulacja. I w jednym, i w drugim przypadku nadzieja metafizyczna jest pozorna, zaś świadomość poświęcenia dla wartości przewyższającej sens i cel Gułagu zerowa. W sytuacji zagrożenia cierpieniem czy śmiercią przeszkodą uniemożliwiającą zaistnienie heroizmu może być strach. Tadeusz Ślipko zalicza go do przeszkód „ograniczających dobrowolność aktów ludzkich”. Określa strach jako stan niepokoju:

„Przez strach rozumiemy stan niepokoju odczuwany przez władze zmysłowe człowieka, a spowodowany zagrożeniem go przez zło trudne do uniknięcia"12.

Według niego strach (metus) mieści w sobie dwa elementy: stan niepokoju oraz określone zło. Obydwa elementy nie stanowią stałej danej. Stanowią natomiast

\footnotetext{
${ }^{10}$ J. Salij, Stowo wstępne, [w:] A. Morka, Doświadczenie Boga w GUŁ-agu, op.cit., s. 6.

${ }^{11}$ E. Ginzburg, Stroma ściana, thum. A. Mandalian, Warszawa, Czytelnik, 2009, s. 593-594.

${ }^{12}$ T. Ślipko, Zarys etyki ogólnej, op.cit., s. 88.
} 
podstawowe kryteria podziału strachu. Z uwagi na wielkość zła Ślipko wyróżnia strach ciężki i lekki. Natomiast z punktu widzenia reakcji uczuciowej - strach niepohamowany oraz umiarkowany:

„W zależności natomiast od stopnia reakcji uczuciowej samej władzy zmysłowej w człowieku odróżnia się tzw. strach niepohamowany oraz strach umiarkowany. Pierwszy zachodzi wówczas, gdy przeżycie strachu jest tak silne, że uniemożliwia całkowicie lub prawie całkowicie swobodę działania bądź rozumu, bądź woli.

Strach umiarkowany polega na przeżyciu stanu lękowego, który mimo zakłócenia, jakie wnosi w działanie duchowych władz człowieka, nie pozbawia go jednak zdolności myślenia i podejmowania decyzji”"13.

Kierując się powyższymi rozróżnieniami, należy podkreślić, iż heroizm w łagrowej anty-przestrzeni i łagrowym anty-czasie był skuteczną próbą opanowania strachu nade wszystko niepohamowanego. Skuteczną próbą zachowania aksjologicznego myślenia, świadomości takiej wartości, dla której należy poświęcić samego siebie.

Ze świadomości więźnia wypływała wola działania w imię wybranej wartości. Świadomość określała pole nadziei, budziła odwagę, rodziła cierpliwość i ,sztukę znoszenia cierpienia" - jak Max Scheler określił postawę akceptacji wszelkiej nieprzyjemności, przykrości i bólu w pochodzącej z 1916 roku rozprawie $O$ sensie cierpienia $^{14}$. Owa „sztuka znoszenia cierpienia” była, jak pokazuje literatura łagrowa, szkołą codziennego cichego heroizmu, który sprawiał, że więźniowie wewnętrznie nie przekształcali się masowo w próchno - o czym pisał Sołżenicyn. Jako forma wyższa od aktywnego oporu przeciwko jego zaistnieniu nie jest definicją heroizmu, ale pozwala zrozumieć jego genezę. Adam Węgrzecki we Wstępie do polskiego wydania rozprawy Schelera wyjaśnia istotę znoszenia cierpienia jako postawę duchową:

„Poddana systematycznemu ćwiczeniu sztuka 'skupiania się' w jedności osoby, milczenia, znoszenia, zastanawiania się nad sobą, kontemplacji, medytacji oraz wiele innych stanów świadomości, których brakuje nam w naturalnym zachowaniu się i w naturalnym światopoglądzie - stały się w tych czasach (początkowe dekady XX wieku), właśnie jako rozszerzenie sfery panowania naszego osobowego ducha na świat wewnętrzny procesów życiowych, co najmniej równie ważne jak materialno-techniczne rozszerzanie sfery naszego ludzkiego panowania nad przyrodą nieożywioną"15.

\footnotetext{
${ }^{13}$ Ibidem, s. 88.

${ }^{14}$ M. Scheler, Cierpienie, śmierć, dalsze życie, tłum. A. Węgrzecki, Warszawa, PWN, 1994.

${ }^{15}$ Ibidem, s. X.
} 
Zarówno w postawie ,aktywnego oporu”, jak i „,sztuce znoszenia” czy „skupiania się" widzimy świadectwo wertykalnie ukształtowanej świadomości, jej ukierunkowanie na wartość wyższa, która warunkuje ofiarę. Scheler podkreśla:

„O 'ofierze' w sensie obiektywnym (w odróżnieniu od swobodnego 'ofiarowania siebie albo czegoś', do czego zdolne są tylko wolne duchowe osoby) można mówić zawsze, ale też tylko wtedy, gdy urzeczywistnienie jakiegoś dobra o porównawczo 'wyższej randze aksjologicznej' okazuje się związane w sposób istotowo konieczny $\mathrm{z}$ unicestwieniem albo pomniejszeniem dobra o porównawczo niższej randze, względnie z ustanowieniem jakiegoś zła znajdującego się na niższym poziome hierarchicznym (Rangstufe)"16.

Ofiara, a więc i heroizm, są wątpliwe wtedy, gdy nie zachodzi ścisła relacja między wymienionymi dwoma poziomami hierarchicznymi wartości. Świadomość osoby przyjmującej cierpienie czy też śmierć musi być bezwarunkowo na te relacje ukierunkowana. W przeciwnym wypadku mielibyśmy bowiem do czynienia z bezmyślnym kaprysem aksjologicznym, tragiczną parodią wolności, która zawsze stanowi warunek odpowiedzialnego wyboru wartości. Dlatego Scheler dopowiada:

„'Ofiara’ jest konieczna tylko wtedy, gdy przyczynowość, jako prawidłowość (zachodząca) między rzeczami i procesami będącymi nosicielami wartości, łączy w konieczny sposób urzeczywistnienie wyższej wartości pozytywnej (względnie uniknięcie zła wyższego rzędu) z ustanowieniem i urzeczywistnieniem zła niższego rzędu"17.

Metafizyczna istota ofiary stanowiącej fundament heroizmu pozwala zrozumieć tych, którzy szafując dla niej własnym życiem, upatrują dla siebie możliwość dalszego istnienia w blasku dobra o wyższej randze aksjologicznej. $Z$ tej perspektywy heroiczna śmierć bądź heroiczne cierpienie nie są tragiczne, nie unicestwiają osoby ostatecznie i totalnie, nie sprowadzają na nią nicości. Z tej perspektywy należy też spojrzeć przede wszystkim na heroizm więźniów „naprawdę religijnych”, o których pisze cytowany wyżej Sołżenicyn, że kroczyli przez Archipelag bez wahania i bez wahania umierali. Według Schelera czynnik ofiary w heroizmie decyduje o jego autentyzmie i zarazem o podmiotowości heroicznej osoby. Jego minimalizacja bądź wyrugowanie sprawiają, iż heroizm traci swe znaczenie i zanika. Przykładem są dla filozofa dzieje szkoły stoickiej, przebiegające według następującej linii spadkowej: od heroicznej walki z cierpieniem poprzez jego przytępianie - Scheler mówi o ascezie przytępienia - następnie stan apatii aż do odrzucenia w ostatniej fazie tego wszystkiego, co cierpienie zrodziło. W ostatecznym rozrachunku stoicyzm nie jest świadectwem

\footnotetext{
${ }^{16}$ Ibidem, s. 12.

${ }^{17}$ Ibidem, s. 13.
} 
heroizmu, lecz przejawem ucieczki od cierpienia, kończącej się tęsknotą za śmiercią i nicością ${ }^{18}$. Podobnie ocenia Scheler proponowane przez Artura Schopenhauera pogodzenie się z losem - a więc i cierpieniem - które jest świadectwem ślepej woli rządzącej światem. Pogodzenie się - skutkujące ucieczką duchową, prowadzące do kontemplacji w filozofii, sztuce, religii - nie przynosi wprawdzie „szczę́liwości”, ale daje „bezbolesność i spokój”. Metafizyczny pesymizm Schopenhauera jest - według Schelera - odpowiedzią na „heroizację historycznego czynu” zaproponowaną przez Kanta, Fichtego oraz Hegla i wyrażającą „staropruskiego ducha walki i wytrwania". Zakładająca ponadto skłonność człowieka do rezygnacji z przyjemności i szczęścia w imię samego tylko heroicznego czynu, nie zaś wartości czyn ten przewyższającej, dającej osobie heroicznej duchową satysfakcję. Jest to „czysty” heroizm, absolutny, w którego ramach - jak pisze Scheler - podejmowane czyny „nie opłacają się” metafizycznie. Taki „czysty” heroizm zakrawa na śmieszność, podobnie jak prezentujący go w literaturze bohater:

„'Absolutny’ bohater nie jest już żadnym bohaterem, lecz durniem albo chorym cierpiącym na algofilię"19

Od krytykowanego przez Schopenhauera „czystego” heroizmu zdecydowanie odbiega chrześcijański heroizm świętych, będący nie tylko ofiarą w imię wartości najwyższej - samego Boga, ale również drogą doskonalenia duchowego. W tym kontekście warto przypomnieć pojęcie heroicznych cnót, sięgające korzeniami myśli św. Tomasza. Cnota heroiczna - jak pisze Jacek Tylka - jest doskonałością zwykłej cnoty, o której Tomasz mówi, że (virtus) jest „stałym usposobieniem czyli nałogiem" - w tym wypadku dobrym. Jest usposobieniem, które motywowało nie tylko świętych męczenników, ale również gorliwych świętych"20. Według Tylki cnota heroiczna jest przejawem samodoskonalenia duchowego i moralnego osoby heroicznej:

„Cnota tedy heroiczna przewyższa zwykłą cnotę, wynosi człowieka ponad poziom innych ludzi i czyni go najpodobniejszym Bogu. Bohater cnoty wykonuje uczynki dobre prędko, bez trudności, z weselem, z pobudki nadprzyrodzonej, a wszystkie te czyny przewyższają zwykły sposób działania, odbywają się bez ludzkiego wyrachowania z zaparciem się działającego i z poddaniem się całkowicie Bogu. (....) Z tego (...) wynika, iż cnota heroiczna działa prędko, bez trudności, z weselem, i z zaparciem siebie samego"²1.

\footnotetext{
${ }^{18}$ Ibidem, s. 48-53.

${ }^{19}$ Ibidem, s. 29.

${ }^{20}$ J. Tylka, O cnotach heroicznych, Kraków 2013, [w:] http://www.ultramontes.pl/tylka_o_cnotach.pdf [dostęp: 21.09.2018].

${ }^{21}$ Ibidem, s. 6-7.
} 
Opisany przez Tylkę rodzaj heroicznego działania nie został przedstawiony w literaturze łagrowej, co nie znaczy, iż łagrowi męczennicy nie osiagnęli świętości. Istotne jest jedno: w każdym przypadku łagrowego heroizmu - sztuce znoszenia cierpienia, aktywnym sprzeciwie wobec jego zaistnienia - mamy do czynienia z przekraczaniem osoby poza własne ja, o którym Marcel w eseju Ja $i$ inni powie, że jest powołaniem osoby ${ }^{22}$. Powołanie to ujmuje w formule: sursum zamiast sum. Wcześniej Scheler w cytowanym eseju zwrócił uwagę na „przekraczanie” jako atrybut osobowego ducha, który pokonuje granice ciała i jego stanów. Owo przekraczanie unaocznia się z całą jaskrawością w sytuacjach granicznych:

„Fenomen wykraczania może jasno się zaprezentować tylko wtedy (...), jeśli dana jest sama śmierć, jeśli człowiek nie tylko wie i sądzi że umrze, lecz żyje 'w obliczu śmierci'"'23.

To ukierunkowanie na śmierć było leitmotivem życia w GUŁagu. Wbrew ideologii komunizmu głoszącej urzeczywistnienie raju na ziemi, łagier mówił o śmierci, świadczył śmierć, zapowiadał śmierć. Zdawać by się więc mogło, że był przestrzenią stymulującą postawy heroiczne. Tym bardziej, że ostatecznym jego sensem i celem był przyspieszony eksperyment antropologiczny - pieriekowka dusz, która była sposobem kształtowania nowego człowieka - osławionego homo sovieticus ${ }^{24}$. Jednak heroiczne postawy - w oczach większości pisarzy łagrowych - nie były normą. Były wyjątkami od normy, dlatego były niezwykle ważne.

Zwracają na nie uwagę wszyscy piszący o Gułagu. Oprócz Sołżenicyna, Szałamowa, E. Ginzburg wymienić należy tutaj m.in. Władimira Bukowskiego czy autorki wspomnień o życiu łagrowym ${ }^{25}$. Szałamow - surowy w ocenie postaw moralnych więźniów - oddaje sprawiedliwość postaciom heroicznym i pokazuje sytuacje, w których więzień wybiera jednak wartości przewyższające jego samego i poprzez bunt - jawny lub wewnętrzny - udowadnia, że sens i cel jego życia są zakorzenione w sferze ponadobozowej - transcendentnej. Podobnie jak Sołżenicyn najwyżej stawia postawę cichego heroizmu więźniów wierzących - religiozników. Należy do nich przedstawiona w opowiadaniu Kursy (Kypcbl) lekarka z obozowego szpitala, Olga Stiepanowna Siemieniak, która nie stała się funkcjonariuszem władzy i wbrew panującym normom rzeczywiście pomaga chorym. W dodatku niektórym - kursantom - proponuje Biblię dla pokrzepienia duchowego.

${ }^{22}$ G. Marcel, Wartość i nieśmiertelność, op.cit., s. 12-28.

${ }^{23}$ M. Scheler, Cierpienie, śmierć..., op.cit., s. 123.

${ }^{24}$ Zob. m.in. A. Raźny, Literatura wobec zniewolenia totalitarnego ..., op.cit.

${ }^{25}$ Zob. W. Bukowski, I powraca wiatr..., thum. A. Mietkowski, London, Polonia, 1983; Historie kobiet z Gułagu. Dusza wciąz boli, praca zbiorowa, red. S. Wileński, thum. A. Kędziorek, Warszawa, Wydawnictwo Naukowe PWN, 2011. 
„Po kilku dniach - pisze narrator - zwróciłem jej książkę. Ta bezreligijność, w której przeżywałem całe swoje świadome życie, nie uczyniła ze mnie chrześcijanina. Ale nie spotkałem w łagrach bardziej godnych ludzi niż tych, oddanych religii. Demoralizacja ogarnęła wszystkich, jedynie oni się trzymali. Było tak i przed piętnastoma laty, i przed pięciu” (t. II, s. 274).

Ta konstatacja ma rangę świadectwa prawdy nie tylko dlatego, że jej autor opiera się na osobistym doświadczeniu Gułagu, ale również dlatego, że jest to doświadczenie osoby „bezreligijnej” - obojętnej religijnie, jednakże niezajmującej pozycji wroga religii - ateisty czy antyteisty. Taka wysoka ocena zachowania więźniów religijnych zbliża Szałamowa do Sołżenicyna, który liczył ich w tysiącach, pisząc o wciąż nowych szeregach niekończącej się ,procesji” łagrowych męczenników. Cichy heroizm religiozników polegał nie tylko na cierpliwym znoszeniu łagrowego losu, ale również na powstrzymywaniu się od zła i podejmowaniu aktów dobra wobec współwięźniów w imię prawdziwego życia po śmierci. Stałym atrybutem tego heroizmu były świadectwa religijności, dawane przez więźniów pomimo prowadzonej przez władze komunistyczne - nade wszystko w łagrach - walce z religią. Modlący się więzień budził respekt - jak pokazuje Szałamow w opowiadaniu Apostoł Раwet (Апостол Павел изфвян) - nie tylko wśród innych więźniów, ale również w szeregach władzy. Bohater opowiadania - Frühsorger - jest traktowany jako ktoś wyjątkowy, zasługujący na szacunek i sympatię, zasadniczo, dlatego że w parze z modlitwą, jaką codziennie odmawiał, szła jego dobroć:

„Codziennie, rano i wieczorem, Frühsorger cicho się modlił, odwróciwszy się od wszystkich i utkwiwszy wzrok w podłodze, a jeżeli już brał udział w ogólnych rozmowach, to jedynie na tematy religijne, a więc bardzo rzadko, gdyż aresztanci nie lubią takich tematów (...) Cały zwiad lubił Frühsorgera, nawet sam Paramonow, któremu Frühsorger zrobił wspaniałe biurko, przepracowawszy przy nim chyba z pół roku" (t. I, s. 56).

Narrator opowiadania podziwia żarliwość religijną Frühsorgera, który w rozmowie z nim pomylił się, zaliczając św. Pawła do grona apostołów. Nie może sobie darować tej pomyłki i oskarża się o grzech zapomnienia. Modli się dodatkowo noca, płacząc i prosząc Boga o lepszą pamięć:

„-- Co z panem - spytałem, doczekawszy końca modlitwy.

Frühsorger znalazł moją rękę i uścisnął ją.

- Ma pan rację - powiedział. - Pawła nie było w liczbie dwunastu apostołów. Zapomniałem o Bartłomieju. - Milczałem.

- Pan się dziwi moim łzom? - powiedział. - To łzy wstydu. Ja nie mogę, nie powinienem zapominać takich rzeczy. To grzech, to wielki grzech” (t. II, s. 57). 
Religioznik w opowiadaniu Szałamowa jest przykładem cichego heroizmu, który wyzwala dobro ze strony ludzi Gułagu - więźniów i łagrowych władz. Gdy się dowiedzieli, że córka przysłała mu list z oświadczeniem, iż wyrzeka się go jako zeka, postanawiają oszczędzić mu bólu i palą przesyłkę z okrutną informacją. Innym przykładem pozytywnego oddziaływania cichego heroizmu religiozników na antyprzestrzeń, anty-komunię i anty-dialog jest postawa tytułowej bohaterki Szałamowa z opowiadania Ciocia Pola (Тётя Поля). Tak została nazwana - jako osoba godna zaufania i wspierająca zeków - więźniarka „sprzątająca” w domu naczelnika obozu. Dzięki swej empatii dla innych, uczciwości i rzetelnej pracy zdobyła zaufanie nie tylko rodziny naczelnika, ale również więźniów, którym świadczyła pomoc - nawet wówczas, gdy z powodu nieuleczalnej choroby znalazła się w łagrowym szpitalu. Ciocia Pola była osobą wierzącą i zażądała księdza, aby się wyspowiadać:

„Wizyta świątobliwego poruszyła cały szpital. Okazało się, w naszej krainie są duchowni! I spowiadają chętnych! W największej Sali szpitalnej, sali nr 2, gdzie zawsze ktoś z chorych opowiadał, pomiędzy obiadem i kolacją, jakieś historie gastronomiczne - nie dla polepszenia apetytu w każdym razie, a z potrzeby wygłodniałego człowieka, dla pobudzenia emocji związanych z odżywianiem - w tej Sali mówiono o spowiedzi cioci Poli" (t. I, s. 125).

Jeszcze większe wrażenie na więźniach - a być może i przebudzenie religijne wywarło pojawienie się na grobie bohaterki krzyża. Ten zakazany symbol religijny, a jednocześnie znak Chrystusa był zwycięstwem zmarłej więźniarki, która swą dobrocią i poświęceniem przemieniła serca rodziny naczelnika, decydującego nie tylko o losach więźnia, ale również o każdym wymiarze życia obozowego i jego antyprzestrzeni. To zwycięstwo było także zasługą ojca Piotra, duchownego, który z determinacją - o jakiej pisał Sołżenicyn - domagał się postawienia krzyża na grobie cioci Poli i umieszczenia na nim napisu z informacją, kto został w tym miejscu pochowany. I to było bezprecedensowym wydarzeniem, gdyż na żadnym grobie nie mógł stać krzyż, na żadnym też nie mógł pojawić się tego typu napis. Wszystkie groby, przeważnie zbiorowe, były anonimowe. Takie wydarzenia zmieniały - przynajmniej na jakiś czas - oblicze łagru:

„I postawiono krzyż, pierwszy na tym cmentarzu. Widać go było z daleka. Chociaż był to krzyż jedyny, cały teren przybrał dzięki niemu charakter prawdziwego cmentarza. Wszyscy mogący poruszać się chorzy chodzili oglądać ten krzyż. I przybitą deseczkę z napisem w czarnym obramowaniu" (t. I. s. 126).

Takich skutków nie przynosiła heroiczna walka o wolność, podejmowana w Gułagu równie rzadko jak dotrzymywanie wierności w sferze religii. Walka więźniów o wolność osiagała najbardziej spektakularny charakter w formie ucieczki z łagru. 
W opowiadaniu Szałamowa Ostatni bój majora Pugaczowa (Последний бой майора Пугачева) tytułowy bohater porywa do takiej ucieczki kilkunastu więźniów i prowadzi ich na wolność jak do bitwy, wiedząc, że lada moment wszyscy mogą zginaćc. I tak się też dzieje, gdyż uciekinierzy nie mogli liczyć na litość miejscowej ludności, która z zimną krwią wskazywała pościgowi ich schronienie. Wszyscy więźniowie, którzy pod „dowództwem” majora Pugaczowa podjęli bój o wolność - ucieczkę zginęli. On sam znalazł na krótko schronienie i zanim popełni samobójstwo, wspomni ich jako heroicznie odważnych, „,najlepszych ludzi jego życia”:

„I leżąc w jaskini, przypomniał sobie swoje życie - trudne, męskie życie, które teraz kończy się na niedźwiedziej ścieżce w tajdze. Wspomniał ludzi - wszystkich, których szanował i kochał, poczynając od swojej matki (...).

Ale najlepszymi, tymi, którzy zasłużyli na pamięć, byli oni, jedenastu jego towarzyszy. Nikt z innych ludzi w jego życiu nie spotkał się z taką ilością rozczarowań, kłamstw i oszustw. I w tym północnym piekle znaleźli jeszcze w sobie siły, aby jemu, Pugaczowowi uwierzyć i sięgnąć po wolność. Byli to najlepsi ludzie jego życia" (t. III, s. 225).

Ich postawa nie mogła być tak doceniona w społeczności łagrowej jak postawa religiozników. Jakikolwiek przejaw sympatii dla uciekinierów mógł bowiem grozić posądzeniem o udzielenie im pomocy, co skutkowało surowymi karami. Podziw dla heroicznej odwagi uciekinierów musiał być głęboko skrywany. Podobnie jak ucieczki traktowano wszelkie próby podejmowania strajku lub buntu. Jeżeli się mimo to zdarzały, były świadectwem heroicznej odwagi w walce z umotywowanym ideologicznie złem społecznym i moralnym, jakie unicestwiało człowieczeństwo zeków. Przykładem takiego walczącego heroizmu jest przedstawiona przez Sołżenicyna w Archipelagu GUŁag historia buntu w specobozie Kengiru - po upadku Berii w 1953 roku - Czterdzieści dni Kengiru (Сорок дней Кенгира). Upór i bohaterstwo zjednoczonych w strajku więźniów politycznych ze zwykłymi przestępcami, błatniakami, sprawił, że władze poszły na czasową ugodę ze zbuntowanymi i zezwoliły im na kontrolowane odgórnie życie i pracę obozu według przygotowanego przez więźniów planu. Jak się okazało, ta ugoda była zabiegiem taktycznym władz, pozwalającym jej strukturom na odbudowanie swoich totalitarnych pozycji w specobozie nie dopuszczających żadnego dialogu z więźniami, a tym bardziej współrządzenia z nimi. Bunt, nazwany powstaniem, miał znaczenie szkoły charakteru dla zbuntowanych. Przebiegał na poziomie aksjologicznym - jako zryw w imię wolności obejmował jednocześnie realizację pozytywnych wartości moralnych. Od politycznych więźniów wymagał otwarcia na przestępców i okazania im zaufania. Od tych drugich - poskromienia przestępczych nawyków i włączenia się w budowę dobra wspólnego. Na przemianie swoich charakterów więźniowie zbudowali jedność. Ta 
właśnie jedność - jako świadectwo moralnego samodoskonalenia buntowników zaskoczyła najbardziej władze obozowe.

„Głównie zaś liczyli panowie dowódcy na to, że knajacy zabiorą się do gwałcenia kobiet, polityczni wystąpią w ich obronie i w rezultacie rozpocznie się wzajemna rzeź. Ale również tu psychologowie z MWD pomylili się! - i to też zasługuje na podziw z naszej strony. Wszyscy świadczą zgodnie, że złodzieje zachowywali się jak ludzie, ale nie $w$ tradycyjnym, używanym przez nich, znaczeniu tego słowa, tylko tak, jak my to rozumiemy. Z kolei - także polityczni i same kobiety odnosili się do nich z wyraźną życzliwością, okazywali im zaufanie. (...) Jeśli kengirskie powstanie miało w sobie jakąś siłę, była to siła jedności. Złodzieje nie czynili również prób rabowania magazynów żywnościowych, co nie mniejsze powinno budzić zdziwienie wśród doświadczonych ludzi. Chociaż w magazynie były zapasy na wiele miesięcy, komisja uradziła, że należy zachować w mocy wszystkie dawne normy przydziału chleba i innych artykułów" (t. III, s. 276).

Bunt poskromiono, wprowadzając do obozu wojsko, które bez skrupułów rozstrzelało najbardziej opornych, ,ponad siedmiuset" - według przytoczonego przez Sołżenicyna oficjalnego raportu władz - rannych wywieziono, a przywódców postawiono przed sądem. Istotna jest tutaj odpowiedź władz na moralne oblicze obozowego powstania - samodoskonalenie i zamanifestowaną zdolność do tworzenia dobra wspólnego. Te jego najważniejsze - aksjologiczne - aspekty można było zniszczyć jedynie przez odwołanie do antywartości - przemocy, kłamstwa, niesprawiedliwości. Te ostatnie wykorzystano do granic możliwości w propagandzie obozowej. Sołżenicyn z wielką przenikliwością demaskuje ją jako instrument sprawowania władzy:

„Ranni zapełnili lazaret obozowy i trzeba ich było wozić również do miejskiego szpitala. (Wolnym zaś wyjaśniono, że wojsko strzelało tylko ślepymi nabojami. A więźniowie sami pozabijali się nawzajem).

Aż się prosiło, aby zmusić pozostałych przy życiu do kopania grobów dla zabitych, ale w końcu zrobiło to wojsko, by rzecz zachować w tajemnicy: trzystu zabitych zakopano w kącie zony, pozostałych zaś hen, w stepie" (t. III, s. 297).

Pisarz podkreśla, że to spektakularne zwycięstwo nad zbuntowanymi więźniami było pozorne. Miało bowiem negatywny fundament aksjologiczny, co sprawiało, że nie mógł się on stać opoką zapewniającą trwanie obozu, stanowiącego instrument nieludzkiej próby realizowania nieludzkiej utopii. Heroiczni więźniowie, pomimo czasowych zwycięstw zła, pojawiali się wciąż na nowo, tworząc ową wielopokoleniową procesję istot dających świadectwo prawdzie i dobru. Wielu było takich, którzy, nie poddając się wewnętrznie, godnie trwali w wierności wartościom ponadobozowym, 
ponadideologicznym - bez buntu, jawnego protestu, spektakularnego aktu heroizmu. Milcząco dochodzili do stanu „dochodiagi”, w którym więzień już tylko oczekuje świadomie śmierci. W tym stanie wyróżnia się cierpliwością, o której Szałamow pisze w opowiadaniu Zielony prokurator (Зеленый прокурор):

„Pozostawało tylko umierać. I umierali, nie myśląc o żadnych ucieczkach, wykazując kolejny raz narodową cechę cierpliwości, sławioną jeszcze przez Tiutczewa i bezwstydnie odnotowywaną przez polityków wszystkich szczebli” (t. II, s. 162).

Owa cierpliwość, jeśli nie towarzyszyła jej skłonność do zła, nie była obojętnością, lecz „sztuką znoszenia cierpienia”, o której mówi Scheler, formą skupienia duchowego, doskonalenia wewnętrznej wolności. Cierpliwi - w tym znaczeniu - więźniowie nie ulegali degradacji moralnej. Sołżenicyn eksponuje ich cierpliwość jako pozytywny atrybut łagrowego życia:

„Poddanie się wyrokom losu, rezygnacja ze świadomego wpływania na kształt własnego życia, przyjęcie do wiadomości, że nie sposób przewidzieć ani tego, co dobre, ani tego co złe - zmniejsza w pewnym stopniu ciężar kajdanów, uspokaja i nawet jakoś oczyszcza człowieka" (t. I, s. 517).

Ten typ heroizmu mógł się wyrazić dodatkowo poprzez stosunek do pracy, której więźniowie ulegający duchowej i moralnej transformacji nade wszystko nienawidzili jako aktywności przymusowej - wbrew talentom, wykształceniu i siłom fizycznym - będącej jawną formą niewolniczego wyzysku. Już w pierwszym swoim utworze o tematyce łagrowej - Jednym dniu Iwana Denisowicza (Один день Ивана Денисовича) Sołżenicyn podkreśla cechującą tytułowego bohatera cierpliwość w znoszeniu obozowego losu poprzez wykonywaną przez niego pracę bez złości, nienawiści do innych - wręcz z zamiłowaniem. Tak wykonywana praca była również formą sztuki znoszenia przeciwieństw, bólu, rozterek duchowych. W tym samym opowiadaniu podkreśla, że więzień zachowywał godność nie tylko w pracy, ale również w baraku - nie szkodząc innym - oraz w stołówce - nie wylizując misek po współwięźniach.

W Archipelagu GUŁag twierdzi, że większość więźniów poddawała się cierpliwie losowi napiętnowanemu przez cierpienie fizyczne i duchowe, które przyjmowali w przeświadczeniu, że kończą się one wraz ze śmiercia, po której zaczyna się lepsze życie - prawdziwe. To samodoskonalenie wewnętrzne tysięcy łagrowych męczenników Sołżenicyn ujmuje jako drogę oczyszczenia rosyjskiego narodu. Mając na uwadze kontekst II wojny światowej, pisze w części pierwszej I tomu - Przemyst więziепnу (Тюремная промышленность): 
„Jest to prawda prosta, lecz dochodzi się do niej przez cierpienia: błogosławione są nie wojny zwycięskie, lecz przegrane! Zwycięstwa potrzebne są rządom, klęski - ludom. Po zwycięstwie chce się dalszych zwycięstw, po klęsce - chce się wolności - i zwykle się ją zdobywa. Klęski potrzebne są ludom tak, jak cierpienia i nieszczęścia poszczególnym ludziom: zmuszają do pogłębienia życia wewnętrznego, do wzniesienia się w życiu duchowym na wyższy poziom” (s. 258).

Podobnie oceniają heroiczne znoszenie łagrowego cierpienia autorki wspomnień opublikowanych w tomie Historie kobiet z Gułagu (Истории женшин из ГУЛага). Znamienne pod tym względem jest wyznanie Olgi Slozberg, która po odbyciu wyroku w łagrze i wyjściu na wolność ponownie trafiła do więzienia na Butyrkach, gdzie oczekiwała na kolejny wyrok. Autorka wykorzystuje tutaj swoje doświadczenie obozowe, udzielając młodszym więźniarkom wielu bezcennych rad przed ich wyjazdem na Kołymę, darząc je matczyną troskliwością i miłością. Pisze:

„Kocham te dziewczyny z jasnymi oczami, które niedługo stracą swój blask i zaczną patrzeć ponuro i bez nadziei na odmianę losu. Kocham je tak mocno, że aż boli mnie serce. Patrząc na nie, wyobrażam sobie moją córkę, która być może w tej samej chwili również miota się w przerażeniu na więziennej pryczy i szuka pociechy i pokrzepienia w oczach starszych. Całą mocą macierzyńskiej miłości chcę wlać w ich serca odwagę i wiarę w życie, w ludzi. Przekonuję je, że ich życie wcale się nie skończyło... [...] One tak bardzo pragną żyć! Proszą, żebym je zapewniła, że w tym strasznym życiu, które je czeka, można zachować czystość, znaleźć prawdziwą miłość. A ja przysięgam im, że będą żyć, pieszczę je jak własne córki, przytulam do siebie i mówię, że najważniejsze, by przeszły przez tę otchłań i ocalały, by nie straciły szacunku do samych siebie" 26 .

Pisarka otwiera młode współwięźniarki na nadzieję i uczy je znoszenia łagrowego cierpienia - postawy cichego heroizmu. Pokazuje, że wierność wysokim wartościom ocali to, co w nich samych najcenniejsze - człowieczeństwo. Ten więzienny czas, w którym stała się nauczycielką godności jako niezbywalnego atrybutu ludzkiego istnienia - również w Gułagu - wspomina pogodnie - jako piękny okres w swoim życiu.

„Trudno uwierzyć, że cztery miesiące spędzone w więzieniu na Butyrkach w 1949 roku wspominam jak piękny okres w moim życiu. Żyłam całą duszą, całym sercem. Czułam się potrzebna. Dziewczęta lgnęły do mnie jak kurczęta do kwoki. Starałam się tak postępować, żeby zrozumiały, że można przejść przez Kołymę i zachować człowieczeństwo. Udało mi się wnieść trochę światła w ten mroczny dla nich czas. Później już

${ }^{26}$ Olga A. Slozberg, [w:] Historie kobiet z Gułagu..., op.cit., s. 124-125. 
taka nie byłam. Byłam przybita i setki razy traciłam wiarę w życie i w ludzi, ale widziałam już, że mam w sobie siłę, której ludzie potrzebują. Ta świadomość opromieniła moje życie" ${ }^{27}$.

Heroiczne postawy w Gułagu podważają nie tylko ideę nowego człowieka homo sovieticus, ale również sens każdej - nie tylko komunistycznej - utopii, która dąży do ukształtowania człowieka pozbawionego wolności ontologicznej, wewnętrznej, moralnej. Człowieka zależnego od determinat ideowych, politycznych, ekonomicznych, cywilizacyjnych. Zdolność osoby ludzkiej do heroizmu, m.in. w Gułagu, jest świadectwem transcendentnego ukierunkowania jego istnienia, a więc również jego wolności.

\section{Literatura}

Ginzburg E., Stroma ściana, tłum. A. Mandalian, Warszawa, Czytelnik, 2009, 632 ss. Marcel G., Homo viator. Wstęp do metafizyki nadziei, thum. P. Lubicz, Warszawa, PAX, 1984, 318 ss.

Morka A., Doświadczenie Boga w GUŁ-agu, Sandomierz, Wydawnictwo Diecezji Sandomierskiej, 2007, 260 ss.

Raźny A. Literatura wobec zniewolenia totalitarnego. Warłama Szałamowa świadectwo prawdy, Kraków, Wydawnictwo Uniwersytetu Jagiellońskiego, 1990, 221 ss.

Scheler M., Cierpienie, śmierć, dalsze życie, tłum. A. Węgrzecki, Warszawa, PWN, 1994, 135 ss.

Sołżenicyn A., Archipelag GUŁag. 1918-1956, tłum. J. Pomianowski, t. I-III (t. I:

363 ss., t. II: 383 ss., t. III: 316 ss.), Warszawa, Nowe Wydawnictwo Polskie, 1991.

Stróżewski W., Istnienie i wartość, Kraków, Znak, 1981.

Szałamow W., Opowiadania kołymskie, tłum. J. Baczyński, t. I-III, Gdańsk, ATEXT 1991.

Ślipko T., Zarys etyki ogólnej, Kraków, WAM, 2004.

Tylka J., O cnotach heroicznych, Kraków 2013, [w:] http://www.ultramontes.pl/tylka_o_cnotach.pdf [dostęp: 21.09.2018].

Walicki A., Marksizm i skok do królestwa wolności. Dzieje komunistycznej utopii, Warszawa, PWN, 1996.

\footnotetext{
${ }^{27}$ Ibidem, s. 126.
} 


\section{References}

Ginzburg E., Stroma ściana [Steep Route], trans. A. Mandalian, Warszawa, Czytelnik, 2009, $632 \mathrm{pp}$.

Marcel G., Homo viator. Wstęp do metafizyki nadziei [Homo Viator: Introduction to a Metaphysic of Hope], trans. P. Lubicz, Warsaw, PAX, 1984, 318 pp.

Morka A., Doświadczenie Boga w GUL-agu [Experiencing God in the GUL-ag], Sandomierz, Wydawnictwo Diecezji Sandomierskiej, 2007, 260 pp.

Raźny A., Literatura wobec zniewolenia totalitarnego. Warłama Szałamowa świadectwo prawdy [Literature in the Face of Totalitarian Subjugation. Varlam Shalamov's Testimony of Truth], Kraków, Wydawnictwo Uniwersytetu Jagiellońskiego, 1990, $221 \mathrm{pp}$.

Scheler M., Cierpienie, śmierć, dalsze życie [On Suffering, Death and Continuing Life], trans. A. Węgrzecki, Warsaw, PWN, 1994, 135 pp.

Sołżenicyn A., Archipelag GUŁag. 1918-1956 [The Gulag Archipelago], trans. J. Pomianowski, Vol. I: 363 pp., Vol. II: 383 pp., Vol. III: 316 pp., Warszawa, Nowe Wydawnictwo Polskie, 1991.

Stróżewski W., Istnienie $i$ wartość [Existence and Value], Kraków, Znak, 1981, 358 pp.

Szałamow W., Opowiadania kołymskie [The Kolyma Tales], trans. J. Baczyński, Vol. I: 232 pp., Vol. II: 321 pp., Vol III: 232 pp., Gdańsk, ATEXT, 1991.

Ślipko T., Zarys etyki ogólnej [An Outline of General Ethics], Kraków, WAM, 2004, $455 \mathrm{pp}$.

Tylka J., O cnotach heroicznych [On Heroic Virtues], Kraków 2013, pp. 33, Available at: http://www.ultramontes.pl/tylka_o_cnotach.pdf [accessed: 21.09.2018].

Walicki A., Marxism and the Leap to the Kingdom of Freedom. The Rise and Fall of the Communist Utopia, Warszawa, PWN, 1966, 536 pp. 
